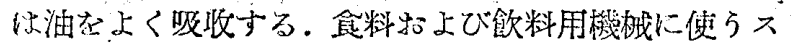
テンレスベァリングは白いよごれない油苑しみ込ませ

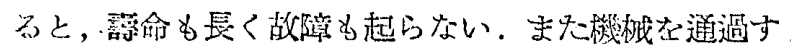

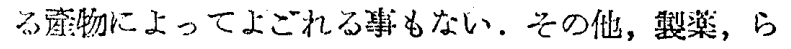

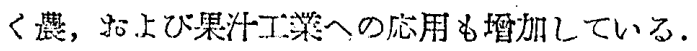

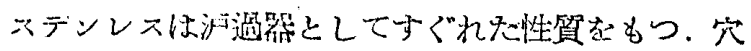

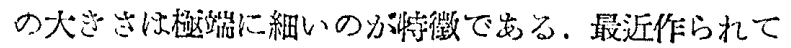

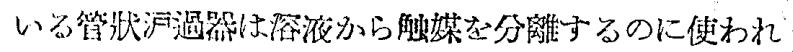
ろ。これら部品の大きさが小さ机ば小さい程, 他の 金愿に比してステンレスの方が良い結果を示してい z. (By courtesy of The Iron Age.)

$621.785 .52: 669.14 .018 .2-155.2$

\section{[岡本 正三]}

\section{[34]軟化表面を克服する復炭処理の実例}

[E. C. Bishop ; American Machinist, 94 (1950)

No. $17,116 \sim 118] \quad \mathrm{H}_{2} 30 \sim 40 \%, \mathrm{H}_{2} \mathrm{O} 00^{\circ} 10 \sim 2 \cdot 00$ $\%, \mathrm{CO} 18 \sim 20 \%, \mathrm{CO}_{2} 0.0 \sim 1.0 \%, \mathrm{CH}_{4} 0 \sim 1 \cdot 5$ $\%$, N.38〜 43\% の組成さもつガスの中で $1400^{\circ} \mathrm{F}$ 以上の適当な溫鹿に加熱することによって，脫炭した 鍋部品の表面をもとの炭素舍量にもどすことができ ふ。

この使用ガスの露点と加㷦溫度とにより传菧の量が 決定される。

復炭処理の実例として次の二つを岁げることができ る.

SAE 1040 ボルト材は高溫厓延の結果約 $0^{\circ} 012$ in

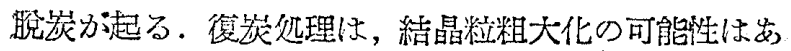
るが，炭素がすみや外㯰換するので $1750^{\circ} \mathrm{F}$ で行 っ先. 露点は $27^{\circ} \mathrm{F}$ 在選じ， $31 / 2$ 時閒加熱し燒準処 理と同様な條件で渝却した。復炭は中心多ら表面まで 均一に行ったが，粘の粗大化涩はなはを゙しいので，2

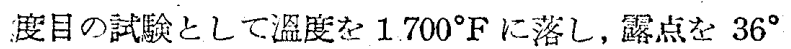
F とし 4 時間処理した. 4 時間にしたのは，所期の復

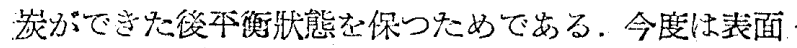
から中心まで均一の荘素会量となり页に結晶粒の大き さ切切断面のどの点に特いても均一で若った。

耧間車用コイル狀スプリングは SAE 6150 棒を高

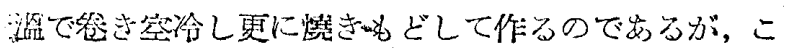
れらの製品の中に使用できなくなるむのが范る。 の原因は，脫笭してやわら名くなった表面に疲的限度

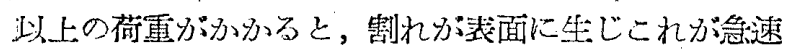
Кひろがるためで岁る。このスプリングの脫炭の樑さ

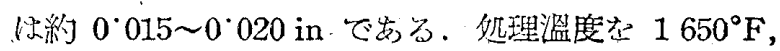

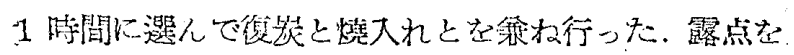

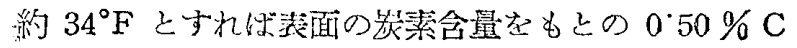
となすことがでさるが，拝面硬度な少し高奴ため，

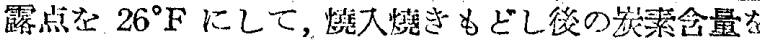

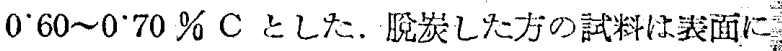

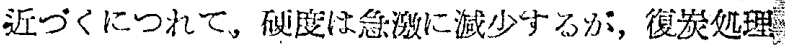
をしたスプリング鍓は琵面のやわらかくなるのを防ざ スプリングとしてト分に役立ち，涛命も婜い。

[誵本 三正]

539.16 .06

\section{[35] 放射性アイソトープの工業的応用}

レオナード・ルール(イギリス科学記者, 前需品省員)

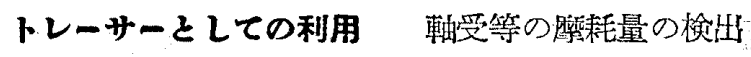
に利用し、メタル娄一定期間原子核パイル中に入れて 一定の放射能を与之これを組立てて通転し，一定時閒 ごとに流出する潤渭油藮めその中に含きれているメ タルの䬺耗量をその放射能により栓出すると微量まで

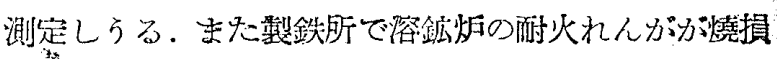
乙終万時期起知りたい場合はれんがの背後に少量の 放癿性コバルト老埋めてその放射能を梌知して括けば よい、コバルトが溶鉄中にとけると放射信号心なたれ。

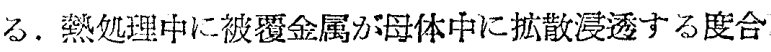
を検出する例として航空譏エンジンのシリンダ・ヘッ ドに対するニッケルがある。放射性ニッケルを用い普

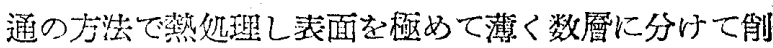
り取り，酸に溶解すると各穈中のニッケル量は椧出し らる。

$\beta$ 線検出器による利用方法菁板物の厚さは任上 んご $\beta$ 線検出器に上り板的の透過量または屈射量を 訐って測定され，その精度も高い，薄板圧延工場で夷 用されている。煙草, 薄膜物, 丸莧等の容器心 $\beta$ 總

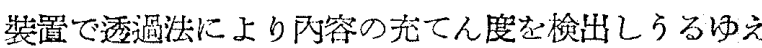
選别用に応用される。

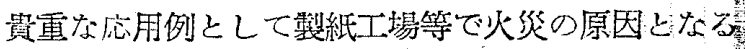

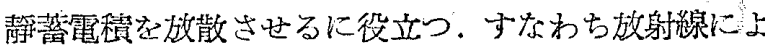

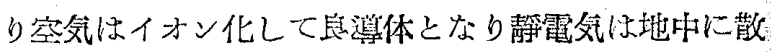
透する。

錩物の欠陷発見用としては防壁を施した空地等で中 央に少量の此較的放射性の强いァイソトープを置き阈 囲に靕物を並へ背後に写貝フィルムを物いて，フイン トープ在雓の器器から出すと露出が始まり約 8 時間志 琹するも簡單で突價なのが利点でをる。

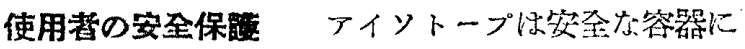
入れてせるのはいう恋でもないダ, British Medical

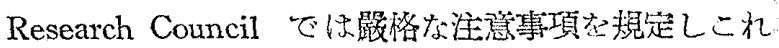

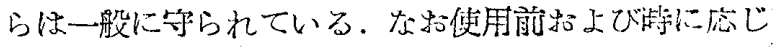

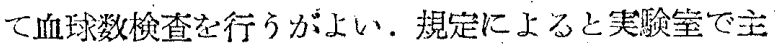

